\title{
Exploration and Analysis on Development of China's Individual Income Tax
}

\author{
Min Luo \\ SIAS International University \\ Zhengzhou University \\ Zhengzhou, China
}

\begin{abstract}
The individual income tax is one of the important taxes in China's tax system, and compared to western developed countries, current individual income tax system in China has a short history and an incomplete design. By absorbing advanced overseas experiences and referring to individual income tax law, based on fundamental realities of China, the paper preliminarily summarized the development trend of individual income tax system in China and put forward opinion on completion of individual income tax system, so as to make the reform of individual income tax system help the economic reform.
\end{abstract}

Keywords—individual income tax; fiscal levy; strategy

\section{INTRODUCTION}

The individual income tax system originated from temporary military expenditure financing of the British government in 1799, in 1874, the individual income tax formally confirmed its status of fixed tax.

\section{A. Concept of Individual Income Tax}

The individual income in individual income tax is not simple accumulation, and there has not been a uniform understanding of its concept in academic circles. The discussion of "theory of increase in net assets" and "theory of source" is widest worldwide.

The representative figure of the "theory of increase in net assets" was Simon, an American economist. He formulated a standard for income based on the space of capital gain, namely the "Hager Simon Concept" which is often mentioned. However, there is a great difference between the idea and practical operation. In actual life, the levy object is stipulated by law, namely the commonly referred tax law income.

The representative figure of the "theory of source" is another economist, Mark. This theory focuses on where the income comes from, namely the reason of income, and he thinks that there is only one fixed source of income, and such income can be gained continuously forever, which shall pay the individual income tax. The "theory of source" stresses fixed and frequent income, excluding the added value of asset itself or transferred income or temporary income.

\section{B. The Development History of China's Individual Income Tax}

China passed "Individual Income Tax Law of the People's Republic of China" in 1980.9, when the individual income tax started to be set up. So far, the individual income tax system has been adjusted for 20 times. In 2011, the exemption volume of individual income tax in Chinese mainland increased to 3500 yuan from 800 yuan.

\section{CURRENT CONDITION OF OUR COUNTRY'S INDIVIDUAL INCOME TAX}

\section{A. The Design of Tax Rate Shall Be Optimized}

Our country's individual income tax system is complicated and the tax rate is high. There are too many tax layers, and it can not certainly play the tax's function of adjusting income and redistribution. Besides, the tax layer is too much divided, which leads to quite a burden of tax collection and management and increases administrative expenditure.

The increase of marginal tax rate means that quite a large portion of the salary shall be used to pay tax, namely the marginal tax rate generated in work decreases. Generally, taking part in labor becomes an "unworthy" thing. In this way the laborer are more inclined to replace labor with leisure, and the labor enthusiasm will decline.

\section{B. The Design of Tax Unit Is Unreasonable}

Our country started to levy individual tax late, and adopted individual contributory system from the beginning of the individual income tax and that is still in use today. On the surface, the individual contributory system realizes the quality among people. However, the individual contributory system does not pay attention to the overall income condition of a family, so the tax bearing may be different when the income is the same.

For example, in some families, both the husband and wife take part in work and the total income is high, but the individual income of each one is not very high, so the tax bearing is relatively light. If only one person works and he or she works hard to support the family and gain high income. In current tax rate, his or her tax bearing will be heavy. Besides, 
the living burden of each family is sometimes personalized such as how many children to get education, how many parents to support and whether there is large medical expense. Only considering the individual income can not fully reflect the living condition and pressure they are facing.

\section{The Collection and Management Force Shall Be Improved}

The collection and management force shall be improved, and the income declaration system lacks supervision. Tax deduction in source is one of the major ways of individual income collection now in our country, and one of the important features of Chinese tax law is that it make clear stipulation to the legal duty of tax payment of the withholding agent, but there is no express term for the volunteer declaration system of ordinary taxpayers. Thus in the process of actual tax collection and management, the individual income collection and management authority has no clear constraint to the ordinary taxpayers, during the volunteer declaration of the taxpayers, the individual income collection and management authority can not get full information. Besides, it's hard to get asset information such as individual credit trading record and cash transfer record, the individual asset is not transparent, and the government lacks necessary support to collect and manage individual income tax. The individual income tax collection and management system is not perfect and reasonable, tax source is greatly lost.

The collection and management force shall be improved, and the collection and management information is not perfect. Tax payers distribute widely, so the tax source is diversified. It needs coordination among various parties to well complete the collection and management. If the collection and management information is perfect and gets spread among various departments, the efficiency of collection and management will be greatly improved. As far as volunteer declaration of individual income tax is concerned, the collection and management department can not effectively verify and the individual can totally declare himself or herself. Setting up perfect system and realizing perfect information are good to improve the collection and management of individual income tax in our country.

The collection and management force shall be improved; the punishment for law violation can not warn people. The people's tax consciousness is thin, and the orderly operation of tax collection and management requires people to have high tax consciousness. With the progress of Chinese economy, people's income source and form become diversified, and the supervising of tax collection and management department becomes harder and harder, under the condition where the tax payer volunteers to declare income, it needs people to have self-conscious tax consciousness. The tax department lacks effective law tool and system tool to effectively restrain the behaviors that prevent the collection and management of individual income tax, which causes failure of effective operation of corresponding tax system.

\section{PROBLEMS EXISTING IN THE DEVELOPMENT OF INDIVIDUAL INCOME TAX}

The gap between the rich and the poor in China is expanding, and Gini coefficient almost exceeds the warning line several times, the function of the individual income tax to adjust income distribution is not well exerted in China.

\section{A. The Classified Income Tax Model Is Unfair}

The classified income tax is still the current taxation model of individual income tax in our country. Its theory basis is the so-called "theory of source" of individual income tax, namely for the same tax payer, it needs to adopt different methods of tax payment according to different classification based on the individual net income for they work on various economic activities.

The classified income tax can hardly reflect the principle of tax equality. For those groups with high comprehensive income and diversified source, the tax bearing is low; however, the groups with low comprehensive income and collective source face high tax bearing. The tax mode can hardly fully reflect the true income level of the tax payer and violates the principle of paying tax based on estimating ability and equity principle.

It's easy for the classified income tax model to breed tax evasion and tax avoidance. Such tax levy model can avoid tax by transferring and decomposing various economic activities. For example, for the tax levy of service income, its important feature is levying in order, and decomposing one-time service into several services, which can decrease the tax rate of each labor tax payment, and even split this service income into several shares to make each service income off the threshold to totally exempt the duty of tax.

\section{B. The Shortage of Tax Levy of Capital Gains in Individual Income Tax}

At present, the scale of stock market is keeping expanding, and it's an international common practice to levy tax for capital gains, which is very necessary for the healthy development of the capital market. At present our country is still deepening financial market reform, and the capital market is still in the stage of continuous development and optimization. It's a major defect for the individual income tax to take in capital gains.

The tax levy system of income from property in our country is not perfect, which cause to too light tax bearing of the groups with high income. However, the large portion of the tax falls over the working class. Besides, many groups which shall pay tax avoid tax due to weak supervision and faint tax consciousness of the people, which prevents the individual income tax system from playing the role of income distribution. The individual income tax designed by good system can prevent speculation in some degree. At the same time, property tax becomes an important method to expand tax source. 


\section{The Expense Deduction Standard of the Individual Income Tax Needs to Adjust}

There is some positive meaning for the continuous improvement of expense deduction standard of the individual income tax, which reduces the tax bearing of the people with low income. However, there are some unreasonable places in the expense deduction standard of our country's individual income tax.

The expense deduction standard of our country's individual income tax imposes uniformity in all cases, which is all the same all over China. The basic principle of levy of individual income tax is to levy tax according to different social economic condition of the tax payer, however, such across-the-board system design adopts the same tax levy standard among tax payers with different economic conditions.

The expense deduction standard of the individual income tax does not take the factor of inflation into account. In current situation, our country has not set up perfect mechanism to realize the effective connection between the current condition of economic development and expense deduction standard of the individual income tax. Thus, when CPI index is high, and the basic living expense of people increases, the tax bearing will markedly reduce the purchasing power of people and generate great life pressure. On the contrary, when the price level is low, the tax bearing is relatively light. In conclusion, there is large fluctuation in the actual individual income tax bearing for the people. Thus, to fully fit the need of economic development, it's necessary to set elastic but not fixed expense deduction standard of the individual income tax.

\section{THE SUGGESTION TO OPTIMIZE THE INDIVIDUAL INCOME TAX IN OUR COUNTRY}

Optimizing the tax system is an important method for system innovation, which shall refer to experience of other countries, start from our country's condition and design the most reasonable system.

\section{A. Adopt Dual Income Tax Model to Fit Equity Principle}

The dual income tax model is a transitional tax model, which effectively refers to the advantage of the classified income tax model and comprehensive income tax and applies to the current condition of China.

Firstly, the dual income tax model executes single tax system in capital income tax, which effectively expands tax base and promotes the increase of fiscal revenue, and can effectively manage the speculative behavior in capital market. Besides, based on improve original classified income tax model and taking the advantage of the comprehensive income tax, it does not raise high claim to the tax system and technical level, which simplifies the tax system in some degree. Executing comprehensive income tax claims high requirement to system design and technical level, however, dual income tax model refers to the advantage of the comprehensive income tax but does not put pressure on the improvement of tax system design and technical level. Besides, the dual income tax model can better fit economic globalization. International capital flow more frequently, and the dual income tax model execute capital gains tax with single tax rate, so it can better promote capital flowing, and reduce tax evasion. In conclusion, the dual income tax model gives consideration to equity principle and keep the advantage of the original system, and is also practical, which reduces levy difficulty and fits the actual condition of our country.

Certainly, the detailed form of dual income tax model shall be decided according to different time and areas of the country. What needs attention here is: firstly, properly handle the tax rates of labor income and capital gains, the difference between which shall not be too large, otherwise the tax payer can transfer labor income into capital income to avoid tax. Secondly, clarify the capital income and labor income of the individual household and private business owner. Our country's law stipulates that the income from production and business operation of the individual household and private business owner also belong to tax payment scale, thus the above division is necessary.

\section{B. Levy Capital Gains Tax}

Firstly, it helps to promote social equity and justice to levy capital gains tax in individual income tax. The levy of capital gains tax conforms to the ability-to-pay principle and equity principle. Levy more tax from groups with more gains, which can narrow the gap between groups with large capital gains and small gains and helps to narrow income distribution gap.

Secondly, levying capital gains tax is necessary for health and stability of capital market. When the capital market is overly prosperous, the investors are actually in a irrational state, due to sheep-flock effect, more people will choose to join in speculative activity of the capital market, and at this time, levying capital gains tax can act as the role of "dose of sobriety" and cool the capital market. When the capital market is relatively depressing, investors' gains are generally low, and the capital gains tax is low, and encourages investors to invest, which is good for recovery of capital market.

Of course, in current individual income tax system, there are some stipulations to capital gains tax, but the systematic arrangement has not been formed. At present, our country's capital market is keeping expanding, and the asset trade is more and more frequent, which will certainly claim higher requirements to the individual income tax reform of our country. The capital gains tax under reasonable law and regulation is necessary for health and stability of the capital market.

\section{Adjust Pre-Tax Deduction System of the Individual Income Tax}

To adjust pre-tax deduction system it shall expand expense deduction items. The "across-the-board" tax levying mode does not consider the actual condition of the family, and the equity of form actually contains real inequity, which does not conform to the requirement of the equity principle. Thus, we can try to expand expense deduction items from the following aspects: firstly, deduct basic expense to make a living, which is both the requirement of international experience and actual condition of our country. Secondly, as 
for the deduction problem of medical expense, to relieve the medical burden of the citizens, expense of medical insurance can be allowed to join in the expense deduction items of the individual income tax. Thirdly, as for education problem, it can be not deducted in areas where free education is executed, but the part of education expense paid by them shall be deducted, which can better popularize compulsory education and improve the cultural quality of our people.

It shall set up elastic mechanism to adjust pre-tax deduction system. Our country's expense deduction is relatively stale, and areas can not adjust with the economic development and rising of CPI. The impact to people's living standard caused by inflation and price rising can not be effectively reflected in the collection and management of the individual income tax, and can not follow the ability-to-pay principle or realize income distribution equity. Thus, it's beneficial to set up effective connection between the expense deduction standard and CPI, adopt indexed expense deduction standard, and adjust in real time annually according to the change of CPI.

\section{CONCLUSION}

With the increasing gap between the rich and the poor, there are some deviations in individual income tax which adjusts individual income, which leads to the condition where people with low income bears high tax but people with high income bear low tax. The function of the individual income tax of adjusting income distribution is not exerted, at the same time; an important defect of the individual income tax is that the individual income tax does not fully take capital income in. The research concludes the developing trend of our country's individual income tax, tries to put forward executing capital gains tax and dual income tax, adjust pre-tax deduction system to optimize our country's individual income tax, and put forward personal opinion to optimize individual income tax.

\section{REFERENCES}

[1] Zhang Qian. Research on the tax rate of our country's individual income tax [D]. Institute of Financial Science of Ministry of Finance, 2013

[2] Yue Ximing, Xu Jing, Liu Qian, Ding Sheng, Dong Lijuan. Income redistribution effect of 2011 individual income tax [J]. Economic research, 2012,v.47;No.53609:113-124.

[3] Peng Haiyan. The empirical analysis of the redistribution effect of our country's individual income tax and progressivity. [J]. Finance \& Trade Economics, 2011,No.35203:11-17.

[4] Xia Hongwei. Research on reform of individual income tax [D]. Institute of Financial Science of Ministry of Finance, 2013.

[5] Liu Yang, Ran Meili, Wang Zhongli. Individual income tax, citizen income distribution and equity-based on empirical comparison between the China and USA's individual income tax [J]. Economic Dynamics, 2014,No.63501:9-17.

[6] Guo Jing. Research on optimizing our country's individual income tax [D]. Institute of Financial Science of Ministry of Finance, 2012

[7] Sun Yijun, Liang Yunfeng. Analysis of effect of individual income tax and strategic suggestion [J]. Journal of Central University of Finance and Economics, 2013,No.30501:13-19.

[8] Joke Felix Sanz-Sanz. The Laffer curve in schedular multi-rate income taxes with non-genuine allowances: An application to Spain[J]. Economic Modelling,2016,221:
[9] Chunyan Pan. Perspective of Problems and Countermeasures by the Analysis of the Collection Data on the Personal Income Tax Collection and Administration of High Income Groups[J]. Open Journal of Social Sciences,2015,0310: 